\title{
ASSET DIVESTITURES AND CORPORATE OPERATIONAL RETURNS: AN AGENCY THEORY PERSPECTIVE ON MALAYSIAN PUBLIC-LISTED COMPANIES
}

\author{
Janice LEE YM ${ }^{1}$, Fauzias Mat NOR ${ }^{2}$ and Norazlan ALIAS ${ }^{3}$ \\ ${ }^{1}$ Centre for Real Estate Studies, Faculty of Geoinformation and Real Estate, Universiti \\ Teknologi Malaysia, Johor Bahru, 81310 Johor, Malaysia \\ E-mail: janicelee@utm.my \\ ${ }^{2}$ Graduate School of Business, National University of Malaysia (UKM), Malaysia \\ E-mail: fauzias@ukm.my \\ ${ }^{3}$ School of Management, National University of Malaysia (UKM), Malaysia \\ E-mail:norazlan@ukm.my
}

Received 9 February 2012; accepted 6 July 2012

\begin{abstract}
Divestitures of property, plant and equipment (PPE) assets are a common form of corporate restructuring. However, divesting companies do not necessarily attain improved post-divestiture shareholder wealth. Studies show company characteristics and use of divestiture proceeds may influence divestiture outcomes. This paper attempts to determine these divesting company characteristics and use of proceeds associated with improved shareholder wealth based on the Agency Theory. A sample of Malaysian public-listed companies that divested assets within 2002-2005 is used. Logistic regression segregates these companies based on their industry-adjusted operational returns. Companies that improve post-divestiture operational performance require urgent pay out motives to divest. Companies with deteriorated post-divestiture performance divest without urgent pay out motive and tend to retain proceeds. This suggests agency problem of managerial discretion in asset divestitures. In asset selection, divestitures of larger and more inefficient assets were found associated with improved company performance. Malaysian companies prefer divesting assets related to their core businesses indicating a diversified company structure is more beneficial than a focused structure in developing countries.
\end{abstract}

KEYWORDS: Asset divestitures; Agency problem; Operational returns; Divestiture proceeds

REFERENCE to this paper should be made as follows: Lee YM, J., Nor, F. M. and Alias, N. (2013) Asset divestitures and corporate operational returns: an agency theory perspective on Malaysian public-listed companies, International Journal of Strategic Property Management, 17(4), pp. 347-360.

\section{INTRODUCTION}

Companies restructure to counter anticipated and ex-post changes in their environment. This paper focuses on property, plant and equipment (collectively termed as 'asset') divestitures, as the most common asset reduction method (Denis and Shome, 2005). Divestitures of such tangible corporate assets are viewed as efficient transfers of corporate resources (Weston et al., 2003) to enhance shareholder wealth. In fact, Moschieri and Mair (2011) explained that divestitures are valuable strategic decisions that could lead to enhanced profit- 
ability and corporate reputation as well as improved market performance.

In general however, divestitures tend to receive minimal academic attention as compared to mergers even though both events involve transfers of ownership and control of corporate assets (Gadad et al., 2009). Most published researches on divestitures attempted to determine whether divesting companies perform better than their non-divesting counterparts. This is usually conducted using matched control samples of non-divesting companies from the same industries (see Schlingemann et al., 2002; Sun, 2012). Many studies found positive association between divestitures and company performance (see e.g. Jain, 1985; Hanousek et al., 2009; Owen et al., 2010; Sun, 2012) while others determined insignificant association (Alexander et al., 1984). A third group found that differing company characteristics, e.g. level of distress (Lasfer et al., 1996) and use of divestiture proceeds (Bates, 2005) are significant variables influencing post-divestiture performance.

The issue that arises from these studies is not all divesting companies attain better postdivestiture performance. Since divestitures are commonly executed by companies attempting to enhance shareholder wealth, it is important to determine the association between divestitures and post-divestiture performance. In fact, Hearth and Zaima (1986) have expressed there is no theory that a priori separates divestitures with positive or negative performance outcomes and till to date, no studies have done so. This study attempts to address this issue by determining company attributes as well as use of divestiture proceeds and their association with subsequent improvement (termed as 'success') or deterioration (denoted as 'failure') divesting companies.

A sample of divesting Malaysian publiclisted companies is used. We chose a developing country since few empirical studies examined divestitures in such an institutional context (Sun, 2012). Furthermore, Hanousek et al. (2009) explained that divestitures are important phenomena in such countries and researches were mainly hampered by inad- equate data. The underlying theory used to develop our hypotheses is the agency theory. This is because according to Markides and Singh (1997), agency theory is the most prominent explanation for corporate restructuring in academic literature.

The implications of this study may be useful to shareholders of public-listed companies to determine how companies' characteristics and use of divestiture proceeds can affect their future wealth. The results may also help regulatory authorities understand how divestitures could enhance company performance or otherwise to improve future regulatory and monitoring purposes. Section 2 discusses the underpinning literature and hypotheses, section 3 describes the data and methodology. Section 4 explains the results and section 5 concludes this study.

\section{LITERATURE REVIEW AND RESEARCH HYPOTHESES}

Based on the wealth-maximizing hypothesis, managers should divest assets when company performance can be improved thus leading to shareholder wealth enhancement. On the contrary, Markides and Singh (1997) found the most prominent explanation among past studies regarding corporate restructuring is the agency theory.

\subsection{Agency theory and asset divestitures}

An agency relationship occurs when a principal (shareholder) delegates some authority to his agent (manager) to perform services on the former's behalf (Jensen and Meckling, 1976). However, agency problems arise when company managers attempt to maximize their own personal utility at shareholders' expense. As a result, company performance deteriorated and consequently, restructuring incidences such as asset divestitures are attempts to correct these agency problems.

Managerial actions symptomatic of agency problems include growth maximization and excessive diversification into various businesses. Company growth is positively related to increases in managerial compensation (Jensen, 
1986) as well as bonuses, stock options and promotions. Prestige and power enjoyed by managers are highly correlated to their company's size and growth as well. For these reasons, managers prefer overseeing larger companies and will embark to maximize company size.

Managers' income from employment constitutes a major portion of their total income and as such, they have very high undiversifiable employment risk (Amihud and Lev, 1981). One of the ways to minimize employment risk is to stabilize the company's income stream as imperfectly correlated earnings stream would reduce variation in the company's overall income. This can be carried out by diversifying the company's line of businesses into different industries.

The agency theory suggests that managers tend to be 'self-serving' at shareholders' expense. As such, Lang et al. (1995) argue that managers will be reluctant to divest assets. Denis and Shome (2005) concurred that since managers' private benefits increases with company size, they will hesitate to reduce the scope of assets under their control.

In Malaysia, the agency relationship in public-listed companies is not between diffused shareholders and managers as depicted by Jensen and Meckling (1976). This is because there is high concentrated share ownership (La Porta et al., 1998), where $40 \%$ of listed companies are family-controlled (Deesomsak et al., 2004), often supplying the top manager (Faccio et al., 2001). As a result, the common agency relationship in Malaysian public-listed companies is between these concentrated owner-manager and minority shareholders. The agency problem that arises is the potential expropriation of minority shareholders, for example, controlling shareholders enrich themselves by not paying dividends (Claessens et al., 1999). This is dubbed as 'crony capitalism' (Lins and Servaes, 2002) where Alias et al. (2010) supported that concentrated ownership in Malaysian companies is not associated with improved post-restructuring performance.

The research hypotheses relating asset divestitures with company performance are de- veloped below based on agency theory and the Malaysian institutional and corporate context.

\subsection{Alleviation of financial constraint as motivation for asset divestitures}

Greater information asymmetry exists between managers and investors in emerging markets, plausibly due to lack of reliable financial reporting and limited analyst following (Lins and Servaes, 2002). Due to poorer access to external funds, the costs of external financing may be more expensive (Beck et al., 2002). Consequently, internal funds become more valuable and the proceeds derived from asset divestitures are one such source. Furthermore, there are fewer deterrents to raise funds through asset divestitures as compared to raising new equity or debt because the buyers are usually well-informed parties from the same industry.

Malaysian companies have low debt levels, in particular, a lower proportion of longterm debt (Booth et al., 2001). This may be attributed to the discrepancy between the cost of external and internal funds. In addition, the average short-term debt ratio is approximately twice that of long-term debt ratio (Pandey, 2001). Therefore, despite lower gearing levels, there is a tendency towards financial constraint when cashflow is insufficient to repay current debt due. The insolvency risks associated with financial constraint threatens the manager's employment and main source of income. As a result, managers' interests become aligned with the shareholders' and they divest assets in order to alleviate financial constraint. Lang et al. (1995) explained that the most compelling motive for divestiture is the urgent need to obtain internal funds because external financing is too costly.

Without any urgent motives to divest, Bates (2005) explained that self-serving managers divest assets to realize substantial increased liquidity at their disposal. Managers may invest in relatively safe projects with suboptimal yield to preserve their personal interest (Easterbrook, 1984) due to their undiversifiable employment risks (Amihud and Lev, 1981). In addition, capital market monitoring can be 
avoided since asset divestitures are mainly private transactions (Slovin et al., 1995).

We posit companies that divest to alleviate financial constraint will have lower agency problems, leading to improved post-divestiture performance as compared to companies without such motive. Hence, the first hypothesis:

H1: Companies that divest to reduce financial constraint will improve post-divestiture performance.

\subsection{Relative size of divested asset and company performance}

Weston et al. (2003) assert that differential relative size of divested assets is the cause of inconsistent shareholder wealth effect in empirical literature. Duhaime and Baird (1987) found that the relative size of divested asset depends on the company's financial strength. Specifically, companies are more attached to larger assets, tied by psychological and economic bonds. Hence, large assets will only be divested under conditions of duress. Bergh (1995) concurs that companies divest large assets for defensive reasons and prefer selling smaller assets as it does not threaten the company's overall revenue stream.

The Securities Commission of Malaysia SC (n.d.) imposes correspondingly greater disclosure requirements for public-listed companies that divest large asset. Firstly, companies divesting assets of at least $5 \%$ "percentage ratio' ${ }^{1}$ must publicly announce via Bursa Malaysia (BM). Companies intending to divest assets with a 'percentage ratio' of at least $25 \%$ will require the prior approval of company shareholders. Divestitures of $100 \%$ percentage ratio and above need the additional approval of the $\mathrm{SC}$, where the subsequent proceeds disbursement will be subjected to monitoring.

1 Percentage ratio is calculated as (i) latest net book value of divested asset against net assets of divesting company, where net assets is defined as share capital + reserves - minority interests; (ii) sale price of divested asset to net assets of divesting company; (iii) sale price of divested asset to market capitalization of divesting company. The largest calculated percentage ratio will be used to represent the relative size of divested asset.
Under these circumstances, we posit that the manifestation of agency problems is greater for companies with smaller asset divestitures. Given a choice, self-serving managers prefer divesting smaller assets (below 25\% percentage ratio) as it is easier to avoid intense scrutiny. The company's income stream will not be affected, hence their employment is preserved. Larger assets would be divested under duress, such as to alleviate urgent financial constraint. The second hypothesis:

$\mathrm{H} 2$ : Companies that divest larger relative size of assets will improve post-divestiture financial performance.

\subsection{Use of asset divestiture proceeds and company performance}

According to the financing hypothesis, companies can use divestiture proceeds to repay shareholders via share repurchase and/ or dividends, repay creditors by servicing debt and retain the proceeds for future investment opportunities. Past studies found that use of divestiture proceeds is associated with differing post-divestiture performance. For instance, Bowman et al. (1999) determined significantly positive wealth impact for payouts and negligible impact for retained proceeds. Hillier et al. (2005) found retained proceeds significantly associated with negative post-divestiture Return On Asset (ROA). Other studies found superior performance for debt payout (e.g. Gadad and Thomas, 2004; Bates, 2005) as opposed to rewarding shareholders or retaining proceeds.

The overall consensus indicates that retention of proceeds is negatively associated with improved post-divestiture performance. The free cash flow theory (Jensen, 1986) explains it is detrimental to leave excess cash at managers' discretion due to their propensity to invest in suboptimal projects. When proceeds are paid out, there is less opportunity for such misuse. As potential expropriation of minority shareholders by controlling shareholders is higher in emerging countries, we posit companies that pay out divestiture proceeds will experienced improved post-divestiture perfor- 
mance compared to companies that retain divestiture proceeds. Hypothesis 3:

H3: Companies that pay out divestiture proceeds will improve post-divestiture performance as compared to companies that retain divestiture proceeds.

\subsection{Asset divestitures to increase company efficiency and focus}

A manifestation of the agency problem is the 'managerial hypothesis' where managers have a propensity to increase the size and diversification (reduce focus) of companies under their control. According to Jensen (1986), growth is positively related to increases in managerial compensation and enlarges the resource base under their control. Managers may grow the company by investing in suboptimal projects which are not beneficial to shareholders. Owen et al. (2010) expressed that managers have a tendency to diversify widely and over-extend their reach in non-core areas of businesses. This is because diversification of companies' businesses will result in imperfectly correlated earnings that could stabilize volatility in the overall income stream. The managers' undiversifiable employment risks can be minimized (Amihud and Lev, 1981). According to the agency theory, suboptimal and diversified investments are symptomatic of the agency problem.

The 'efficient deployment hypothesis' theorizes that a divesting company gains when the market perceives the asset was profitably divested (Lang et al., 1995). For example, when the divested asset is surplus to company's requirements or had interfered with its business operations (John and Ofek, 1995). This should result in higher post-divestiture efficiency of the remaining assets in the company (Gadad and Thomas, 2004). Relating to agency theory, divestitures of such inefficient assets may be viewed as attempts to remedy past agency mistakes of managerial excesses and inefficiencies (Markides and Singh, 1997).

We posit that divestiture of inefficient assets, whether surplus or that produce dise- conomies with the company will improve postdivestiture performance. Hence, hypothesis 4:

$\mathrm{H} 4$ : Companies that increase post-divestiture efficiency by divesting inefficient assets will improve in performance.

Lins and Servaes (2002) explained that companies facing difficulties in securing external financing compensate by diversifying their business to create internal capital markets. As mentioned above, this may aggravate potential agency problems - which were found positively related to diversification. This is because the opaque dealings of diversified companies allow greater potential expropriation of minority shareholders (Mitton, 2002) as compared to their focused counterparts. Furthermore, Francoeur and Niyabahwe (2009) explained that the internal capital markets of diversified companies are less efficient in allocating capital, which is associated with lower company value.

As a result of diversification, Lang and Stulz (1994) found that diversified companies have lower value (Tobin's q) compared to single-industry companies. This value loss or 'diversification discount' can be mitigated when assets in peripheral (non-core) businesses are divested (Berger and Ofek, 1995) as compared to divesting related assets (John and Ofek, 1995). According to Hatfield et al. (1996), focused companies tend to perform better due to improved factor specialization and managerial efficiency. DePamphilis (2010) summarizes that divestitures can create value by increasing the diversified company's focus, reducing diversification discount by transferring the assets to others who can use them more effectively and eventually reduces agency conflicts.

Lins and Servaes (2002) found over $47 \%$ of Malaysian companies were diversified. Their entire sample of Asian countries shows a diversification discount of $7.7 \%$. In an earlier study, Claessens et al. (1998) determined least segmental complementarities amongst Malaysian companies. The main concern of Lins and Servaes (2002) is how diversification could compound agency problems in emerging coun- 
tries, supporting DePamphilis (2010) assertion that divestitures could reduce such agency conflicts. It is easier for controlling shareholders to manage diversified companies for their personal interest. In fact, the authors suggest that the potential expropriation of minority shareholders is the basis for diversification discount in emerging countries.

A contrasting view on diversification by Khanna and Palepu (1997) explained that the conglomerate form (highly diversified) company is particularly suited to the institutional context of most emerging countries where external capital markets are less developed. In fact, Fauver et al. (2003) found that conglomerates tend to perform better, i.e. trade at diversification premium, in developing countries. Their results on Malaysian companies reveal positive, non-significant relationship between corporate value and level of diversification.

We posit companies that increase focus by divesting non-core assets signify attempts to reduce diversification discount and rectify agency problems of over-diversification. However, the positive mitigating effect of diversi- fication on companies in developing countries may render the results insignificant. Hypothesis 5:

H5: Companies that increased focus by divesting non-core assets will improve post-divestiture performance.

\section{DATA AND METHODOLOGY}

The performance impacts of divestitures are typically analyzed using very short-term event studies. For example, Sun (2012) uses an event window of [-150days; +30days] and Owen et al. (2010) uses [-1day; +1day]. This study however adopts a longitudinal timeframe as Bergh (1997) determined persistent impact of divestitures beyond the short-term. We chose the timeframe of Denis and Shome (2005) and Hillier et al. (2005) respectively of 3years pre[-3yr; $-1 \mathrm{yr}]$ and 3years post-divestiture [+1yr; $+3 y r$. Similar to Gadad et al. (2009), we determine one pre-divestiture and one post-divestiture averaged measure of performance for each divesting company. The research model is shown in Figure 1.

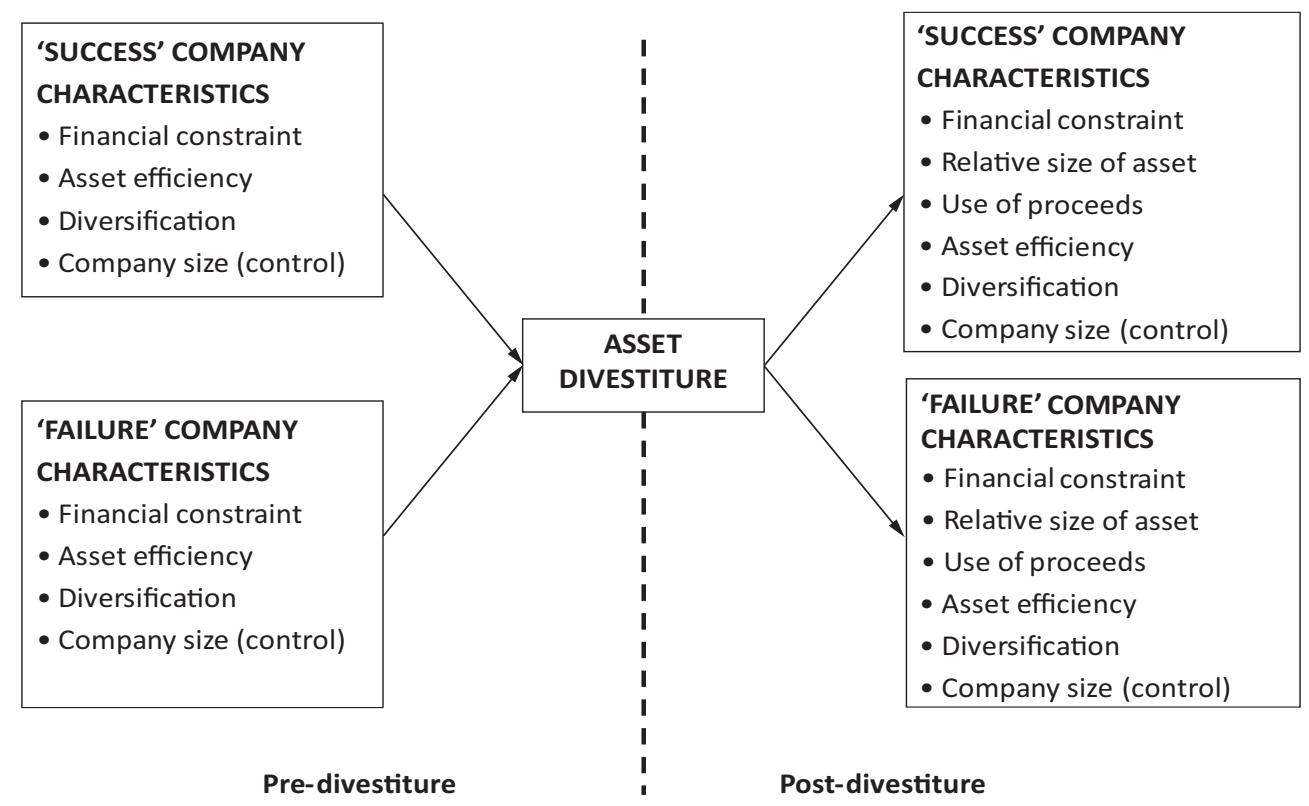

Figure 1. Research model 


\subsection{Sample and data sources}

The sample consists of asset (PPE) divestitures of public-listed companies in Malaysia. Details of divesting company announcements are obtained from BM website and the announcement dates will be as stated. The corresponding historical financial data for each divesting company is sourced from Datastream and Osiris databases.

The sample of divestitures is constrained within 2002-2005. This is to limit the total study period including [-3yr; $-1 \mathrm{yr}]$ and [+1yr; $+3 y r]$ to 1999-2008, a period of stable economic growth in Malaysia. We selected this timeframe because economic cycles could affect the volume and price level of asset divestitures. For example, Ting (2006) ascertained differing wealth effect for divestitures under buoyant and recession economic conditions in Malaysia. More companies were found to divest in recessions (Alexandrou and Sudarsanam, 2001) as the profitability of companies are negatively impacted by tight fiscal and monetary policies. Yang (2008) found that asset prices peaked during recovery and will bottom out when the economy slides into recession.

We applied a few exclusions on the study sample. Firstly, only divestitures of 5\% percentage ratio and above must be publicly an- nounced (as mentioned in section 2.2). This means companies divesting below this ratio may choose to announce on voluntary basis. Such divestitures are excluded to avoid bias sampling. Second, related party divestitures (e.g. between an unlisted subsidiary and its parent company) are excluded because the effects of divestiture and acquisition in each transaction are hard to disentangle. Next, divesting companies from the financial sector are removed due to differing financial characteristics and use of leverage (Pandey, 2001). Only divestitures in exchange for cash are included (those involving equity exchange are removed). Finally, for companies conducting multiple divestitures, only the first announced divestiture (at least 5\% percentage ratio) will be taken into account as in Kaiser and Stouraitis (1995).

\subsection{Variables measures}

The performance measure adopted is ROA, as it is the most informative measure of operating performance for asset divestitures (Denis and Shome, 2005). Each divesting company's performance is industry-adjusted against the relevant sectors determined by BM. Studies such as Haynes et al. (2002) argue that accounting-based measures may be manipulated

Table 1. Independent variables measures

\begin{tabular}{ll}
\hline Independent variable & Measure \\
\hline Financial constraint (FINCON) & Dummy variable $(1=$ constrained) \\
& EBITDA < $80 \%$ of interest expense on debt \\
Relative size of divested asset (RELSIZE) & Percentage ratio calculation \\
Use of Proceeds (companies can select more & 2 Dummy variables $(1=$ yes) \\
than 1 category) & Pay debt (PAYDEBT); Retain (RETAIN) \\
Asset efficiency (EFF) & Fixed asset turnover [Sales/Total assets] \\
Focus (FOCUS) & Sales-based Herfindahl index \\
& {$\left[\right.$ H $=\Sigma \mathrm{S}_{\mathrm{i}}{ }^{2} /\left(\Sigma \mathrm{S}_{\mathrm{i}}\right)^{2}$ ] where the sum of squares in each segment $i$ 's } \\
& sales, $S_{i}$, as a proportion of total sales of the company \\
& Results in a figure between 0-1. The closer to 1 , the greater \\
& the focus \\
Company size (COSIZE) & Control variable \\
& Log (total assets) \\
\hline
\end{tabular}


in the year of divestiture to result in spurious performance of divesting companies. In order to accurately reflect the actual impact of divestitures on company performance, the authors suggested a longer timeframe beyond the divestiture year.

Each company's post-divestiture [+1yr; +3yr] performance is compared to its pre-divestiture [-1yr; -3yr] performance. To minimize random fluctuations in returns, pre- and post-divestiture returns are averaged as in Liao (2005). Companies that experience improved performance is classified as 'success' whereas those with deteriorated performance as 'failure'.

The independent variables are financial constraint, relative size of divested asset, use of proceeds, level of efficiency and focus. The measures are summarized in Table 1.

For financial constraint, we use 'interest expense on debt' rather than 'current debt due' since companies are obliged to at least service interest payments on its outstanding debt without risking default. The $80 \%$ threshold is used because Asquith et al. (1994) found that companies would only react when their EBITDA falls below this level.

\subsection{Estimation method}

Logistic regression is used to contrast 'success' and 'failure' companies based on independent variables in (i) pre-divestitures (ii) divestiture year (iii) post-divestiture periods respectively.

The empirical model:

$$
\mathrm{Y}_{\mathrm{i}}=\mathrm{e}^{\mathrm{u} /}\left[1+\mathrm{e}^{\mathrm{u}}\right] \text {. }
$$

The dependent variable $=1$, event (success).

For pre-divestiture, $\mathrm{u}=\left(\mathrm{a}+\beta_{1}[\mathrm{FINCON}]+\right.$ $\beta_{2}[\mathrm{EFF}]+\beta_{3}[$ FOCUS $\left.]+\mathrm{b}_{4}[\mathrm{COSIZE}]\right)$.

For divestiture and post-divestiture, $\mathrm{u}=$ $\left(\mathrm{a}+\beta_{1}[\right.$ FINCON $]+\beta_{2}[$ PAYDT $]+\beta_{3}[$ RET $]$ $+b_{4}[$ EFF $]+b_{5}$ [FOCUS $]+b_{6}[$ RELSIZE $]+$ $\mathrm{b}_{7}$ [COSIZE]).

Use of divestiture proceeds (PAYDT and RET) and relative size of divested asset (RELSIZE) is only known at year of divestiture, hence not included in the pre-divestiture regression.

\section{EMPIRICAL RESULTS AND DISCUSSION}

As logistic regressions are susceptible to multicollinearity, we determine zero-order correlation coefficients amongst the independent variables (results not shown). No variables are significantly correlated (above 0.80) so there is no significant multicollinearity according to Gujerati (2003).

\subsection{Sample descriptive statistics}

A total of 395 asset divestitures were announced within 2002-2005. From this, 67 divestitures fall below $5 \%$ percentage ratio, 4 divestitures from financial companies and 37 divestitures from companies with inadequate information. After taking into account the first significant divestiture from each company (at least 5\% percentage ratio), there were $132 \mathrm{sub}$ sequent divestitures from these companies. All these are excluded and the final sample consists of 155 companies where approximately $59 \%$ of divesting companies are 'failure' to improve post-divestiture performance (91 companies) and only 64 companies are 'success'. Table 2 summarizes the sample's descriptive statistics.

The relationship between ROA and independent variables in pre- and post-divestiture periods are shown in Table 3. To take into account the longitudinal timeframe of the sample, Generalized Least Squares regressions are used in a panel data.

ROA is significantly associated with negative financial constraint in both pre- and postdivestiture periods. This means divesting companies should pay greater attention to alleviate financial constraint for higher likelihood of improved post-divestiture performance. Efficiency is positively related to ROA but significant in pre-divestiture period only, indicating partial support for the wealth-maximization hypothesis. Larger companies are significant and positively associated with ROA in predivestiture only. To remove this effect of company size, it is included as a control variable in the empirical model. 
Table 2. Divesting companies descriptive statistics

\begin{tabular}{|c|c|c|c|c|}
\hline & $\begin{array}{l}\text { Company classifi- } \\
\text { cation }\end{array}$ & Pre-divesture & Post-divesture & $\mathrm{p}$-values \\
\hline \multirow{4}{*}{$\begin{array}{l}\text { Company size } \\
\text { (RMmil) }\end{array}$} & \multirow[t]{2}{*}{ Failure } & $\$ 999.86$ (avg) & $\$ 971.82$ (avg) & -0.030 \\
\hline & & $\$ 358.82$ (med) & $\$ 356.75$ (med) & 0.490 \\
\hline & \multirow[t]{2}{*}{ Success } & $\$ 1130.59$ (avg) & $\$ 1286.27$ (avg) & 0.891 \\
\hline & & $\$ 313.58$ (med) & $\$ 321.42$ (med) & 0.750 \\
\hline \multirow{4}{*}{$\begin{array}{l}\text { Relative size of } \\
\text { divested asset } \\
\text { (percentage ratio } \\
\text { and RMmil) }\end{array}$} & \multirow{2}{*}{\multicolumn{2}{|c|}{ Failure }} & \multicolumn{2}{|l|}{$22.91 \%(\$ 40.41 \mathrm{mil})$ avg } \\
\hline & & & \multicolumn{2}{|l|}{$14.84 \%(\$ 10.30 \mathrm{mil}) \mathrm{med}$} \\
\hline & \multirow{2}{*}{\multicolumn{2}{|c|}{ Success }} & \multicolumn{2}{|l|}{$41.34 \%(\$ 82.84 \mathrm{mil})$ avg } \\
\hline & & & $19.19 \%(\$ 10.69 \mathrm{mil}) \mathrm{med}$ & \\
\hline \multirow{4}{*}{$\begin{array}{l}\text { Efficiency (total } \\
\text { asset turnover) }\end{array}$} & \multirow[t]{2}{*}{ Failure } & 0.555 (avg) & 0.558 (avg) & 0.319 \\
\hline & & 0.418 (med) & 0.418 (med) & 0.127 \\
\hline & \multirow[t]{2}{*}{ Success } & 0.574 (avg) & 0.673 (avg) & 0.036 \\
\hline & & 0.423 (med) & 0.525 (med) & 0.074 \\
\hline \multirow{4}{*}{$\begin{array}{l}\text { Focus (sales- } \\
\text { based Herfindahl } \\
\text { index) }\end{array}$} & \multirow[t]{2}{*}{ Failure } & 0.683 (avg) & 0.658 (avg) & -0.498 \\
\hline & & 0.669 (med) & 0.635 (med) & -0.202 \\
\hline & \multirow[t]{2}{*}{ Success } & 0.695 (avg) & 0.672 (avg) & -0.713 \\
\hline & & 0.673 (med) & 0.661 (med) & -0.828 \\
\hline
\end{tabular}

Table 3. Estimates of GLS regressions with ROA as dependent variable

\begin{tabular}{llll}
\hline $\begin{array}{l}\text { Independent } \\
\text { variable }\end{array}$ & $\begin{array}{l}\text { Pre-divestiture }[-3 y r ;-1 y r] \\
\text { coeff. }\end{array}$ & $\begin{array}{l}\text { Post-divestiture [+1yr; +3yr] } \\
\text { coeff. }\end{array}$ \\
\hline C & -0.188 & $* *$ & -0.027 \\
FINCON & -0.161 & $* * *$ & -0.057 \\
RELSIZE & & & 0.001 \\
EFF & 0.028 & $* * *$ & 0.016 \\
FOCUS & 0.027 & & 0.04 \\
PAYDEBT & & & -0.008 \\
RETAIN & & & -0.012 \\
COSIZE & 0.036 & $* * *$ & 0.000 \\
\hline
\end{tabular}

where: [-3yr;-1yr] denotes annualized average values for pre-divestiture years $1-3 .[+1 \mathrm{yr} ;+3 \mathrm{yr}]$ denotes annualized average values for post-divestiture years $1-3$.

\subsection{Company attributes associated with improved post-divestiture performance}

The results of the empirical model are shown in Table 4. Significant variables are financial constraint, relative size of divested asset and retention of proceeds.

\subsubsection{Improved performance associated with reduced financial constraint}

'Success' companies have significantly higher financial constraint in pre-divestiture period, which is then significantly lowered in postdivestiture. This indicates 'success' companies 


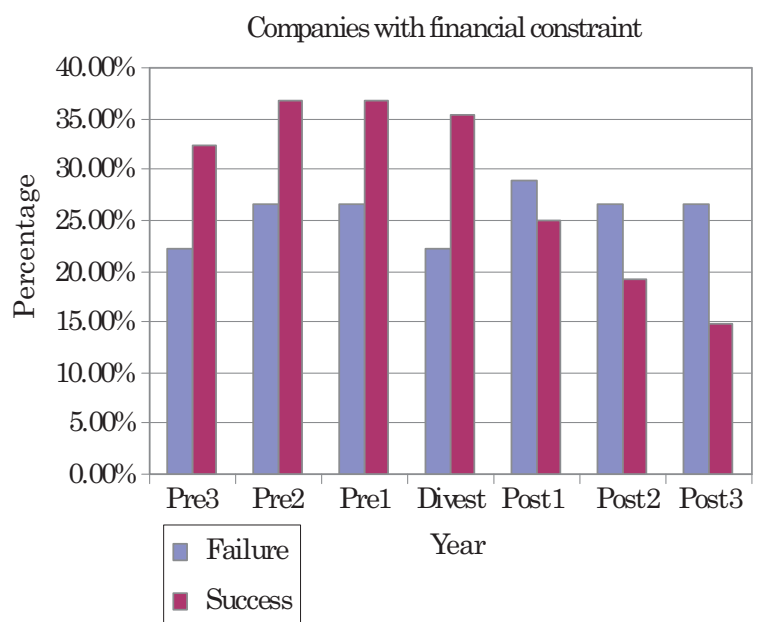

Figure 2. Companies with financial constraint

are more likely to divest to alleviate financial constraint. Hypothesis 1 is supported.

Figure 2 illustrates that more than 35\% of 'success' companies were financially constrained in pre-divestiture and divestiture years. In post-divestiture years 2 and 3, financial constraint is significantly reduced to less than $20 \%$ and $15 \%$ respectively. The results for 'success' companies indicate support for Lang et al. (1995) where managers divest only when compelled to due to debt service. When the company faces default risk that threatens managers' employment, their interests will be aligned with the shareholders'. Managers will act on shareholders' best interest by focusing on minimizing financial constraint.
On the other hand, 'failure' companies had lower financial constraint in pre-divestiture years but higher in post-divestiture. The explanation by Bates (2005) describes 'failure' companies where managers voluntarily divest without financial constraint. They converted illiquid assets to cash to be utilized at their discretion. 'Failure' companies prefer raising funds through private transactions such as asset divestitures as capital market monitoring can be avoided. Furthermore, 'failure' companies subsequently experience post-divestiture financial constraint, suggesting that divestiture proceeds had later become unavailable. This demonstrates possible investments in suboptimal projects by 'failure' companies, since they experienced lower post-divestiture ROA. The results support the assertion by Easterbrook (1984) where managers invest in relatively safe projects with suboptimal yield to preserve their personal interests at shareholders' expense.

\subsubsection{Improved performance associated with larger relative size of divested assets}

Relative size of divested asset is significant and positively associated with 'success' companies in divestiture and post-divestiture years. Specifically, Table 2 shows that 'success' companies divested approximately $41 \%$ percentage ratio (around $\mathrm{RM} 82$ million) as compared to $23 \%$ (about RM40mil) for 'failure' companies.

Table 4. Summary of logistic regressions

\begin{tabular}{|c|c|c|c|}
\hline $\begin{array}{l}\text { Independent } \\
\text { variables }\end{array}$ & $\begin{array}{l}\text { Pre-divestiture }[-3 \mathrm{yr} ;-1 \mathrm{yr}] \\
\text { coeff. }\end{array}$ & $\begin{array}{l}\text { Divestiture year [Yr 0] } \\
\text { coeff. }\end{array}$ & $\begin{array}{l}\text { Post-divestiture }[+1 \mathrm{yr} ;+3 \mathrm{yr}] \\
\text { coeff. }\end{array}$ \\
\hline $\mathrm{C}$ & -3.454 & -2.448 & -2.108 \\
\hline FINCON & 1.293 & 0.192 & -1.431 \\
\hline RELSIZE & & 1.623 & 2.055 \\
\hline $\mathrm{EFF}$ & 0.285 & 0.408 & 0.112 \\
\hline FOCUS & 0.119 & 0.139 & 0.404 \\
\hline PAYDT & & 0.284 & 0.543 \\
\hline RETAIN & & -0.592 & -0.712 \\
\hline COSIZE & 0.443 & 0.268 & 0.253 \\
\hline
\end{tabular}

Successful companies = event, 1 ; Failure companies $=$ non-event, 0 .

'Financial constraint' is indicated by dummy variable, where: $1=$ constrained, $0=$ otherwise. 'Pay debt' is a dummy variable, where: 1 = pay debt, 0 = otherwise. Ditto for 'retain proceeds'. 
Hence, hypothesis 2 is supported. The discrepancy between monetary value and percentage ratio is because 'success' companies are larger than 'failure' companies. However, the difference in company size is not statistically significant.

'Success' companies were compelled to divest large assets defensively even though this places them under greater scrutiny. The results support earlier findings on hypothesis 1 where more than $1 / 3$ of 'success' companies endured pre-divestiture financial constraint. On the other hand, 'failure' companies divested slightly lower than the $25 \%$ percentage ratio. By maintaining the relative size of divested asset below this threshold, 'failure' companies manage to avoid mandatory shareholder approval to divest assets. These findings indicate support for the agency theory where larger assets are divested under duress. Combined with the results in hypothesis 1 , companies with prior urgent and compelling motive to divest large assets tend to perform better in enhancing shareholder wealth. Companies without such prior motives divest smaller assets in order to avoid intense scrutiny for self-serving interests.

\subsubsection{Improved performance associated with proceeds used to pay debt}

'Success' companies have significantly negative propensity to retain divestiture proceeds but higher (not statistically significant) tendency to pay debt. The results indicate that 'failure' companies are more likely to retain proceeds and less likely to pay debt. Hypothesis 3 is supported.

Relating the results to hypothesis 1, 'success' companies mainly used divestiture proceeds to pay debt as they urgently needed to reduce financial constraint. 'Failure' companies do not face high pre-divestiture financial constraint, so they have a tendency to retain proceeds instead.

The findings support Jensen (1986) where proceeds retained at managers' discretion causes agency problems that are detrimental to company performance. Furthermore, none of the divesting companies rewarded sharehold- ers using the divestiture proceeds so Claessens et al. (1999) may be correct to state that dividends are withheld at minority shareholders' expense. It could also indicate that Malaysian companies do not practice rewarding shareholders with divestiture proceeds.

\subsubsection{Improved performance related to higher efficiency and reduction in focus}

Efficiency is positively related to 'success' in asset divestitures but the relationship is not statistically significant. This is probably because 'success' companies were more efficient than 'failure' companies in both pre- and postdivestiture periods, as shown in Table 2. However, the improvement in efficiency is significant for 'success' companies, with an increase in average total asset turnover ratio of 0.10 (from 0.574 in pre-divestiture to 0.673 in postdivestiture) whereas 'failure' companies experienced insignificant improvement (from 0.555 to 0.558 ). Hence, hypothesis 4 is only partially supported.

The results show 'success' companies paid greater attention in selecting inefficient assets to divest than 'failure' companies. Markides and Singh (1997) determined that divestitures of inefficient assets are viewed as effort to remedying prior managerial excesses. The efficiency of the remaining assets in the company improves, leading to enhanced shareholder wealth.

Focus is also not a significant variable associated with 'success' companies in asset divestitures. Similar to efficiency, this could be attributed to 'success' companies being consistently more focused that 'failure' companies in both pre- and post-divestiture years. However, both subsamples experienced reduction in focus from pre- to post-divestiture. According to Table 2, 'success' companies experienced average reduction in Herfindahl index from 0.695 to 0.672 . 'Failure' companies also reduced focus from 0.683 to 0.658 - a magnitude equivalent to 'success' companies. Hence, hypothesis 5 is not supported.

This means the average company in the sample became more diversified by divesting assets that were related to its core business, 
although the change in focus is not statistically significant. Hence, the results denote support for studies such as Fauver et al. (2003) and Khanna and Palepu (1997) that diversification is beneficial for companies in developing countries. The benefits of increased diversification such as creation of internal capital markets to compensate for lower external financing sources seem to outweigh its disadvantages in this context. The results contradict studies that document greater potential expropriation of minority shareholders (such as Lins and Servaes, 2002) and value loss from diversification discount (Berger and Ofek, 1995; John and Ofek, 1995) that leads to lower shareholder wealth.

\section{CONCLUSION AND IMPLICATIONS}

The wealth-maximization hypothesis proposed that managers divest assets in order to improve company performance and ultimately shareholder wealth. However, studies tend to concur with agency theory instead and suggest that managers value growth maximization and will divest only when compelled to, e.g. the urgent need for internal funds because external sources are scarce or expensive (Lang et al., 1995).

Using a sample from an emerging country, Malaysia, the results of this study show strong influence of agency problems in asset divestitures of public-listed companies. We found large assets are predominantly divested by financially constrained companies that are compelled to divest in order to repay debt. These companies seem to improve post-divestiture performance. On the contrary, 'failure' divesting companies without the pressure of financial constraint tend to divest smaller assets to minimize external scrutiny and retain proceeds. These 'failure' companies subsequently face post-divestiture financial constraint, and as performance deteriorated, indicating that divestiture proceeds are already invested in suboptimal projects.

None of the divesting companies rewarded shareholders using divestiture proceeds. This may be a manifestation of the agency problem as predicted by Claessens et al. (1999), or because it is not normal practice for Malaysian companies. As shown by the positive association between efficiency and 'success' companies, selection of assets that are more inefficient increases the likelihood of improved post-divestiture performance.

The average divesting company in Malaysia will select assets from their core businesses to divest rather than peripheral businesses. Contrary to studies in developed countries which promote increasing company focus, divesting companies in Malaysia view that reducing focus (increasing diversification) will lead to improved performance. This is plausibly due to the benefits of diversified companies such as creation of internal capital markets that are more valuable to a developing country.

The implication of these results to investors is that for companies to 'succeed' in asset divestitures amidst the agency problems, companies must face urgent need to raise funds where divestiture proceeds are paid out and not retained. Investors should be wary of companies that divest without compelling purposes. Investors should also view divestitures of assets from the core businesses in a positive light as such divestitures may not necessarily hamper future company performance. For regulatory authorities, they may wish to pay greater attention to the subsequent actions of companies that retain proceeds.

\section{REFERENCES}

Alexander, G. J., Benson, P. G. and Kampmeyer, J. M. (1984) Investigating the valuation effects of announcements of voluntary corporate sell-offs, Journal of Finance, 39(2), pp. 503-517. http://dx.doi. org/10.1111/j.1540-6261.1984.tb02323.x

Alexandrou, G. and Sudarsanam, S. (2001) Shareholder wealth effects of corporate selloffs: impact of growth opportunities, economic cycle and bargaining power, European Financial Management, 7(2), pp. 237-258. http://dx.doi.org/10.1111/1468-036X.00154

Alias, N., Nor, F. M. and Yaacob, M. H. (2010) The effects of ownership structure on asset restructuring performance, American Journal of Finance and Accounting, 2(1), pp. 75-93. http://dx.doi.org/10.1504/ AJFA.2010.034569 
Amihud, Y. and Lev, B. (1981) Risk reduction as a managerial motive for conglomerate mergers, Bell Journal of Economics, 12(2), pp. 605-617.

Asquith, P., Gertner, R. and Scharfstein, D. (1994) Anatomy of financial distress: an examination of junk-bond issuers, Quarterly Journal of Economics, 109(3), pp. 625-658. http://dx.doi.org/10.2307/2118416

Bates, T. W. (2005) Asset sales, investment opportunities, and the use of proceeds, Journal of Finance, 60(1), pp. 105-135. http://dx.doi.org/10.1111/j.15406261.2005.00726.x

Beck, T., Demirgüç-Kunt, A. and Maksimovic, V. (2002) Financing patterns around the world: the role of institutions, World Bank Policy Research Working Paper 2905, World Bank: Washington D.C.

Berger, P. G. and Ofek, E. (1995) Diversification's effect on firm value, Journal of Financial Economics, 37(1), pp. 39-65. http://dx.doi.org/10.1016/0304405X(94)00798-6

Bergh, D. D. (1995) Size and relatedness of units sold: an agency theory and resource-based perspective, Strategic Management Journal, 16(3), pp. 221-239. http://dx.doi.org/10.1002/smj.4250160306

Bergh, D. D. (1997) Predicting divestiture of unrelated acquisitions: an integrative model of ex-ante conditions, Strategic Management Journal, 18(9), pp. 715-731. http://dx.doi.org/10.1002/(SICI)10970266(199710)18:9<715::AID-SMJ912>3.0.CO;2-6

Booth, L., Aivazian, V., Demirguc-Kunt, A. and Maksimovic, V. (2001) Capital structures in developing countries, Journal of Finance, 56(1), pp. 87-130. http:// dx.doi.org/10.1111/0022-1082.00320

Bowman, E. H., Singh, H., Useem, M. and Bhadury, R. (1999) When does restructuring improve economic performance? California Management Review, 41(2), pp. 33-54.

Claessens, S., Djankov, S., Fan, J. and Lang, L. (1998) Diversification and efficiency of investment by East Asian corporations, Policy Research Working Papers Series, No. 2033. World Bank: Washington D.C.

Claessens, S., Djankov, S., Fan, J. and Lang, L. (1999) Expropriation of minority shareholders in East Asia. [Online]. Available at: http://www.ssrn.com [accessed 25 October 2009]

Deesomsak, R., Paudyal, K. and Pescetto, G. (2004) The determinants of capital structure: evidence from the Asia Pacific region, Journal of Multinational Financial Management, 14(4-5), pp. 387-405. http://dx.doi. org/10.1016/j.mulfin.2004.03.001

Denis, D. K. and Shome, D. K. (2005) An empirical investigation of corporate asset downsizing, Journal of Corporate Finance, 11(3), pp. 427-448. http://dx.doi. org/10.1016/j.jcorpfin.2004.04.003

DePamphilis, D. (2010) Mergers, acquisitions and other restructuring activities: an integrated approach to processes, tools, cases and solutions. $5^{\text {th }}$ Edition. California: Academic Press.

Duhaime, I. M. and Baird, I. S. (1987) Divestment decision-making: the role of business unit size, Journal of Management, 13(3), pp. 483-498. http://dx.doi. org/10.1177/014920638701300305

Easterbrook, F. H. (1984) Two agency-cost explanations of dividends, American Economic Review, 74(4), pp. 650-659.

Faccio, M., Lang, L. H. P. and Young, L. (2001) Dividends and expropriation, American Economic Review, 91(1), pp. 54-78. http://dx.doi.org/10.1257/aer.91.1.54

Fauver, L., Houston, J. and Naranjo, A. (2003) Capital market development, international integration, legal systems and the value of corporate diversification: a cross-country analysis, Journal of Financial and Quantitative Analysis, 38(1), pp. 135-157. http:// dx.doi.org/10.2307/4126767

Francoeur, C. and Niyubahwe, A. (2009) Sell-offs, internal capital markets, and long-run performance: Canadian evidence, International Journal of Managerial Finance, 5(4), pp. 376-390. http://dx.doi. org/10.1108/17439130910987530

Gadad, A. M., Stark, A. W. and Thomas, H. M. (2009) Divestitures: wealth transfers or real economic gains?, Applied Financial Economics, 19(13), pp. 1073-1081. http://dx.doi.org/10.1080/09603100701335440

Gadad, A. M. and Thomas, H. M. (2004) Do asset sales lead to improvements in operating performance? Applied Economics, 36(8), pp. 865-871. http://dx.doi.or $\mathrm{g} / 10.1080 / 0003684042000229578$

Gujerati, D. (2003) Basic econometrics. $4^{\text {th }}$ Edition. New York: McGraw-Hill.

Hanousek, J., Kočenda, E. and Svejnar, J. (2009) Divestitures, privatization and corporate performance in emerging markets, Economics of Transition, 17(1), pp. 43-73. http://dx.doi.org/10.1111/j.14680351.2009.00334.x

Hatfield, D. E., Liebeskind, J. P. and Opler, T. C. (1996) The effects of corporate restructuring on aggregate industry specialization, Strategic Management Journal, 17(1), pp. 55-72. http://dx.doi. org/10.1002/(SICI)1097-0266(199601)17:1<55::AIDSMJ788>3.0.CO;2-B

Haynes, M., Thompson, S. and Wright, M. (2002) The impact of divestment on firm performance: empirical evidence from a panel of UK companies, Journal of Industrial Economics, 50(2), pp. 173-196. http:// dx.doi.org/10.1111/1467-6451.00173

Hearth, D. and Zaima, J. K. (1986) Divestiture uncertainty and shareholder wealth: evidence from the U.S.A. (1975-1982), Journal of Business Finance \& Accounting, 13(1), pp. 71-85. http://dx.doi. org/10.1111/j.1468-5957.1986.tb01173.x

Hillier, D., McColgan, P. and Werema, S. (2005) Asset sales, operating performance and firm strategy: an empirical analysis. [Online]. Available at: www.ssrn. com SSRN-id650166(1) [accessed 18 March 2009]

Jain, P. C. (1985) The effect of voluntary sell-off announcements on shareholder wealth, Journal of Finance, 41(1), pp. 209-224. http://dx.doi. org/10.1111/j.1540-6261.1985.tb04945.x 
Jensen, M. C. and Meckling, W. H. (1976) Theory of the firm: managerial behavior, agency costs an ownership structure, Journal of Financial Economics, 3(4), pp. 305-360. http://dx.doi.org/10.1016/0304405X(76) $90026-\mathrm{X}$

Jensen, M. C. (1986) Agency costs of free cash flow, corporate finance, and takeovers, American Economic Review, 76(2), pp. 323-329.

John, K. and Ofek, E. (1995) Asset sales and increase in focus, Journal of Financial Economics, 37(1), pp. 105126. http://dx.doi.org/10.1016/0304-405X(94)00794-2

Kaiser, K. and Stouraitis, A. (1995) Value creation through corporate restructuring: European divestitures, $\mathrm{Eu}$ ropean Management Journal, 13(2), pp. 164-174. http://dx.doi.org/10.1016/0263-2373(95)00004-5

Khanna, T. and Palepu, K. (1997) Why focused strategies may be wrong for emerging markets, Harvard Business Review, 75(4), pp. 41-51.

La Porta, R., Lopez-de-Silanes, F., Shleifer, A. and Vishny, R. W. (1998) Law and finance, Journal of Political Economy, 106(6), pp. 1113-1155. http://dx.doi. org/10.1086/250042

Lang, L. P. H. and Stulz, R. M. (1994) Tobin's q, corporate diversification, and firm performance, Journal of Political Economy, 102(6), pp. 1248-1280.

Lang, L., Poulsen, A. and Stulz, R. (1995) Asset sales, firm performance, and the agency costs of managerial discretion, Journal of Financial Economics, 37(1), pp. 3-37. http://dx.doi.org/10.1016/0304405X(94)00791-X

Lasfer, M. A., Sudarsanam, P. S. and Taffler, R. J. (1996) Financial distress, asset sales, and lender monitoring, Financial Management, 25(3), pp. 57-66.

Liao, J. (2005) Corporate restructuring, performance and competitiveness: an empirical examination, Competitiveness Review, 15(1), pp. 33-48. http://dx.doi. org/10.1108/10595420510818687

Lins, K. V. and Servaes, H. (2002) Is corporate diversification beneficial in emerging markets?, Financial Management, 31(2), pp. 5-31. http://dx.doi.org/10.2139/ ssrn. 282419

Markides, C. and Singh, H. (1997) Corporate restructuring: a symptom of poor governance or a solution to past managerial mistakes?, European Management
Journal, 15(3), pp. 213-219. http://dx.doi.org/10.1016/ S0263-2373(97)00002-9

Mitton, T. (2002) A cross-firm analysis of the impact of corporate governance on the East Asian financial crisis, Journal of Financial Economics, 64(2), pp. 215-241. http://dx.doi.org/10.1016/S0304-405X(02)00076-4

Moschieri, C. and Mair, J. (2011) Successful divestitures need proper cultivation, IESE Insight, 9, $2^{\text {nd }}$ Quarter, pp. 50-57.

Owen, S., Shi, L. and Yawson, A. (2010) Divestitures, wealth effects and corporate governance, Account ing \& Finance, 50(2), pp. 389-415. http://dx.doi. org/10.1111/j.1467-629X.2009.00332.x

Pandey, I. M. (2001) Capital structure and the firm characteristics: evidence from an emerging market, IIMA Working Paper No. 2001-10-04. Indian Institute of Management: Ahmedabad.

Schlingemann, F. P., Stulz, R. M. and Walkling, R. A. (2002) Divestitures and the liquidity of the market for corporate assets, Journal of Financial Economics, 64(1), pp. 117-144. http://dx.doi.org/10.1016/S0304405X(02)00073-9

Securities Commission of Malaysia (n.d.) Equity guidelines. [Online]. Available at: http://www.sc.com.my [accessed 20 October 2009]

Slovin, M. B., Sushka, M. E. and Ferraro, S. R. (1995) A comparison of the information conveyed by equity carve-outs, spin-offs, and asset sell-offs, Journal of Financial Economics, 37(1), pp. 89-104. http://dx.doi. org/10.1016/0304-405X(94)00796-4

Sun, M. (2012) Impact of divestiture activities on corporate performance: evidence from listed firms in Taiwan, International Journal of Business and Finance Research, 6(2), pp. 59-67.

Ting, K. H. (2006) Impact of the Asian financial crisis on corporate real estate disposals, Journal of Corporate Real Estate, 8(1), pp. 27-37. http://dx.doi. org/10.1108/14630010610664787

Weston, F., Mitchell, M. and Mulherin, H. (2003) Takeovers, restructuring and corporate governance. $4^{\text {th }}$ Edition. New Jersey: Pearson Education.

Yang, L. (2008) The real determinants of asset sales, Journal of Finance, 63(5), pp. 2231-2262. http://dx.doi. org/10.1111/j.1540-6261.2008.01396.x 